\title{
MANAJEMEN KAS MAJELIS TAKLIM UNTUK PEMBERDAYAAN EKONOMI
}

\author{
Ellen Rusliati \\ ellenrusliati44@gmail.com \\ Mulyaningrum \\ Universitas Pasundan
}

\begin{abstract}
ABSTRAK
Tujuan memiliki uang kas adalah untuk motif transaksi, spekulasi, dan berjaga-jaga. Bagi majelis taklim dapat pula digunakan untuk pemberdayaan ekonomi umat, sesuai dengan tujuan pendiriannya, yaitu dengan memanfaatkan kas yang tersedia, sebagai hasil tabungan anggota untuk keperluan Idul Fitri/Adha, disalurkan menjadi pinjaman jangka pendek bagi anggota atau warga sekitar yang memiliki usaha mikro. Pelaksanaan program dilakukan secara daring. Skema yang dapat digunakan adalah mudharabah atau qardhul hasan. Penyaluran kredit harus dilakukan secara hati-hati, karena dana yang digunakan adalah amanah umat yang harus dikembalikan pada waktunya. Prinsip yang digunakan dalam pemilihan pengusaha yang memperoleh kredit melalui 5C dan 3R (Character, Capacity, Capital, Collateral, Condition, Risk bearing ability, Return, Repayment Capacity). Manajemen kas tetap harus menerapkan prinsip good governance, sehingga kepercayaan pemilik dana semakin bertambah. Hasilnya menunjukkan bahwa penyaluran kredit dilakukan bagi usaha mikro penduduk sekitar, pemilihan dilakukan berdasarkan kesepakatan pengurus, dilakukan secara hati-hati dan pencatatan yang memadai, sehingga dapat memperbesar usaha.
\end{abstract}

Kata Kunci: manajemen kas; majelis taklim; pemberdayaan ekonomi; kredit; good governance

\section{PENDAHULUAN}

Penciptaan lapangan kerja dapat dilakukan melalui pemanfaatan potensi yang dimiliki untuk memanfaatkan peluang yang tersedia. Upaya ini akan menumbuhkan usaha mikro dengan segala kekurangannya. Tahap-tahap permulaan berwirausaha (pada umumnya usaha kecil), yaitu: (1) tahap imitasi (duplikasi), (2) pengembangan, (3) menciptakan sendiri barang dan jasa. Usaha yang baru berdiri rentan untuk gagal, walaupun banyak yang berhasil. Jika menggunakan konsep life cycle maka tahap introduction memerlukan dukungan yang kuat agar dapat bertahan. Tahap pengembangan menuntut pengelolaan usaha lebih baik, sehingga usaha berkembang, baik dari segi pendapatan, laba, jenis produk, aset, dan sebagainya. Hasil penelitian (Rugui, Lincoln and Omagwa, 2018) menunjukkan bahwa usaha kecil memerlukan sumber dana tambahan, meningkatkan inovasi dan penelitian, jaringan dan kerja sama dengan semua pihak terutama institusi keuangan.

(Fox \& Romero, 2017) menyatakan pemberdayaan ekonomi diperlukan untuk mengembangkan outcome, pertumbuhan, pengurangan kemiskinan, dan hak asasi manusia. Pemberdayaan ekonomi merupakan bagian dari pemberdayaan lainnya, yaitu sosial - budaya, keluarga/antar individu, hukum, politik, dan psikologis. Outcome pemberdayaan ekonomi dapat diukur berdasarkan Tabel 1. 
Tabel 1

Outcome Pemberdayaan Ekonomi

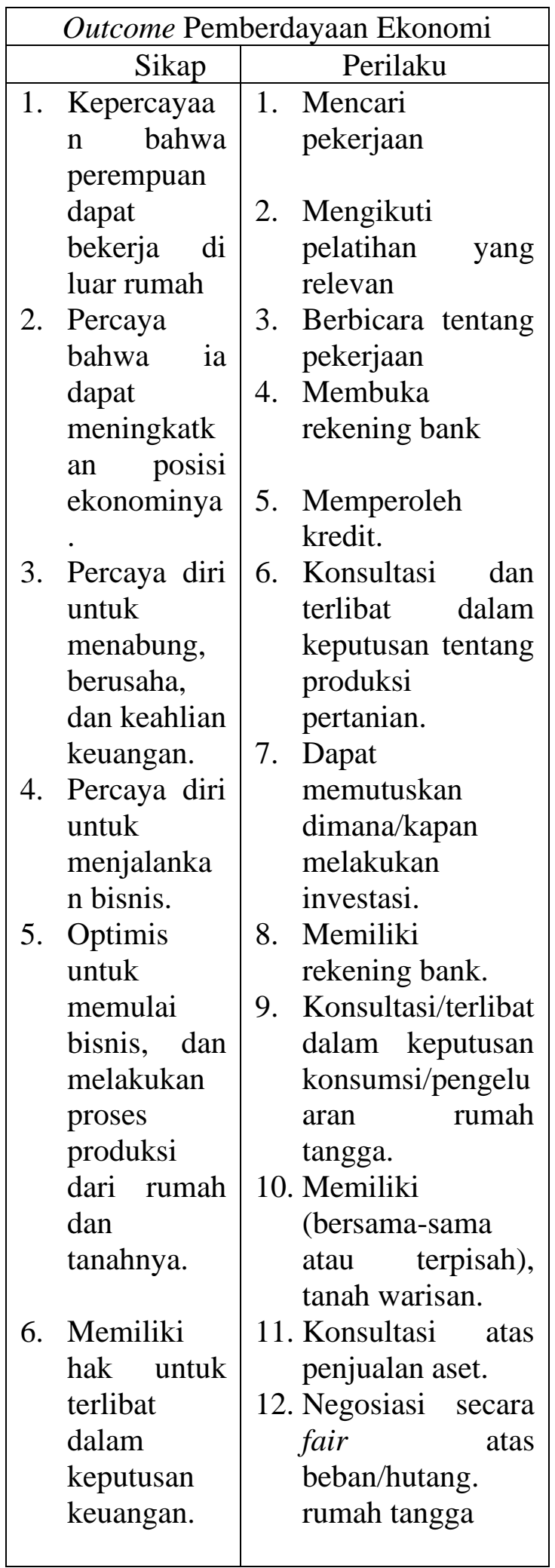

\section{Memiliki kebebasan untuk menerima dan memanfaatk an pendapatann ya. \\ 8. Percaya bahwa rumah tangga harus melakukan investasi untuk mengurangi beban rumah tangga/laki- laki harus juga melaksanak an beban rumah tangga.}

Sumber: (Fox \& Romero, 2017)

Hasil penelitian (Ipansyah \& Helmi, 2014) menunjukkan bahwa $90 \%$ materi pengajian yang diberikan dalam kegiatan majelis taklim (MT) menyangkut pembelajaran tauhid, fikih ibadah, akhlak/tasawuf. materi pengajian yang secara khusus mempelajari fikih muamalah ditemukan pada $10 \%$. Muamalah adalah segala peraturan yang diciptakan Allah untuk mengatur hubungan manusia dengan manusia dalam hidup dan kehidupan. hubungan kepentingan antar sesama manusia (Jazil, 2014). Muamalah merupakan tema yang penting bagi MT menurut (Ramlah, 2017). Hasil penelitian (Huda, 2020) menunjukkan bahwa MT dapat memberdayakan masyarakat dalam bidang spiritual keagamaan, ekonomi, pendidikan, dan sosial kemasyarakatan. 
Pengertian kas setara kas adalah suatu pos-pos yang dianggap sama dengan kas, misalnya sekuritas jangka pendek yang segera jatuh tempo dan investasi sementara yang sangat likuid. Kas adalah alat pembayaran yang siap dan bebas dipergunakan untuk membiayai kegiatan umum organisasi. Kepemilikan kas (cash holdings) adalah jumlah kas yang dimiliki oleh organisasi. Jika kas yang dimiliki cukup atau tidak berlebihan maka dapat mengindikasikan likuiditas dan profitabilitas yang baik. Manajemen kas yang tepat meningkatkan koordinasi, menghemat biaya dan mengurangi kerugian dan stres manajemen/staf. Manajemen kas yang tepat perlu dijadikan budaya organisasi dan strategi yang berorientasi tujuan (Nso, 2018). Keynes (1936) dikutip oleh (Van Horne, James C; Wachowicz, John M., 2012) mengemukakan tiga motif menahan uang kas, yaitu: (1) transaksi untuk memenuhi pembayaran, seperti pembelian, upah, pajak, dan dividen, (2) spekulasi memanfaatkan peluang yang ada, seperti penurunan tiba-tiba harga bahan baku, (3) berjaga-jaga, mempertahankan batas keamanan untuk memenuhi kebutuhan kas di luar perkiraan.

Majelis Taklim (MT) adalah lembaga atau kelompok masyarakat yang menyelenggarakan pendidikan keagamaan Islam nonformal sebagai sarana dakwah Islam. MT menyelenggarakan fungsi; (a) pendidikan agama Islam bagi masyarakat, (b) pengkaderan Ustadz dan/atau Ustadzah, pengurus, dan jemaah, (c) penguatan silaturahmi, (d) pemberian konsultasi agama dan keagamaan, (e) pengembangan seni dan budaya Islam, (f) pendidikan berbasis pemberdayaan masyarakat, (g) pemberdayaan ekonomi umat, dan/atau, (h) pencerahan umat dan kontrol sosial dalam kehidupan berbangsa dan bernegara (Indonesia, 2019).
Pengabdian kepada masyarakat ini difokuskan pada fungsi MT sebagai pemberdayaan ekonomi umat. Seperti dikemukakan imam besar masjid Istiqlal Jakarta, Nasruddin Umar (2018) yang dikutip oleh (Huda, 2020) bahwa jumlah MT di Indonesia pada tahun 2018 kurang lebih sebanyak 250.000 buah. Jumlah MT yang banyak belum berbanding lurus dengan peningkatan kualitas masyarakat Islam. Pengabdian kepada masyarakat ini bertujuan untuk berkontribusi pada MT Ummahat Al-Abror Kec. Arcamanik, kota Bandung, Jawa Barat agar dapat berperan dalam pemberdayaan ekonomi mikro melalui manajemen kas. Selanjutnya dapat menjadi percontohan bagi MT lainnya, sehingga kontribusi terhadap muamalah akan semakin tinggi.

Pada umumnya MT memiliki uang kas yang diperoleh dari anggota sebagai uang tabungan/titipan dalam jangka pendek sebagai tabungan untuk Hari Raya Idul Fitri/Adha. Uang kas tersebut tersimpan di bendahara, merupakan dana menganggur dan sudah dapat diperkirakan waktu pengambilannya. Tabungan tersebut dapat digunakan untuk disalurkan dalam bentuk pinjaman jangka pendek dengan sistem bagi hasil kepada para pengusaha mikro yang dimiliki anggota atau warga setempat untuk memperbesar modal usahanya. Jenis pembiayaan yang dapat dipilih adalah mudharabah dan al-qardh.

Pembiayaan mudharabah adalah pembiayaan yang dilakukan oleh Lembaga Keuangan Syariah (LKS) kepada pihak lain untuk suatu usaha yang produktif. Akad mudharabah adalah akad kerja sama suatu usaha antara pemilik modal (malik/shahib al-mal) yang menyediakan seluruh modal dengan pengelolaan ('amil/mudharib) dan keuntungan usaha dibagi di antara mereka sesuai nisbah yang disepakati dalam akad (DSN-MUI, 2017). 
Al-Qardh adalah pinjaman yang diberikan kepada nasabah (muqtaridh) yang memerlukan. Nasabah al-Qardh wajib mengembalikan jumlah pokok yang diterima pada waktu yang telah disepakati bersama. Biaya administrasi dibebankan ke nasabah (DSN MUI, 2001). Jika nasabah tidak dapat mengembalikan sebagian atau seluruh kewajibannya pada saat yang telah disepakati, maka jangka waktu pengembalian dapat diperpanjang, atau menghapus (write-off) sebagian atau seluruh kewajibannya.

Penyaluran kredit kepada pengusaha harus dilakukan secara hati-hati, guna menghindarinya terjadinya kredit macet. Perlu dilakukan seleksi terhadap debitur yang mengajukan kredit, yaitu meliputi 5 C (Gitman, Lawrence J. and Zutter, 2015) yaitu: (1) character, catatan pemohon kredit memenuhi kewajibannya di masa lalu, (2) capacity, kemampuan pemohon kredit untuk mengembalikan, (3) capital, posisi hutang dibandingkan modal sendiri yang dimiliki, (4) collateral, jumlah aktiva yang dimiliki pemohon untuk menjamin kredit, (5) condition, kondisi ekonomi dan industri baik secara umum dan khusus. dan $3 \mathrm{R}$, (1) return, yaitu, tingkat keuntungan yang dihasilkan atas dana yang dipinjam, (2) repayment capacity, kemampuan debitur untuk mengembalikan pinjaman, dan (3) risk bearing ability, kemampuan debitur untuk menghadapi risiko yang timbul dan dapat mengakibatkan kerugian.

Pengelolaan kas yang menganut prinsip good governance akan meningkatkan kepercayaan anggota, sehingga tertarik untuk menyimpan dananya di kas MT dengan harapan kas yang dimiliki dapat memberi manfaat kepada yang membutuhkan. The United Nations Economic and Social Comission for Asia and the Pacific (UNESCAP) mendefinisikan governance sebagai proses pengambilan keputusan dan implementasinya (UNESCAP, 2013). Good governance adalah proses yang memenuhi karakteristik: (1) accountability, (2) transparent, (3) follow the rule of law, (4) responsive, (5) equitable and inclusive, (6) effective, (7) efficient, (8) participatory. Hasil penelitian (Dhaoui, 2019) menunjukkan bahwa good governance dimulai dengan identifikasi mekanisme, proses, dan outcomes. Institusi memegang peran penting untuk menerapkan good governance agar dapat berkontribusi peda lingkungan yang sesuai untuk mekanisme pengembangan yang berkelanjutan, sehingga dapat mengembangkan rencana dengan lebih efektif, efisien, dan bertanggung jawab

\section{METODE}

Metode pengabdian pada masyarakat dilakukan secara daring pada bulan Februari 2021, dengan peserta pengurus dan anggota MT Ummahat AlAbror, Kecamatan Arcamanik, Bandung. Informasi selanjutnya diperoleh melalui komunikasi dengan ketua, penasihat, dan anggota MT.

\section{HASIL}

Penyusunan laporan kas MT Ummahat Al-Abror dilakukan setiap bulan oleh bendahara dan dilaporkan ke ketua sebagai penanggung jawab. Kas terdiri dari kas umum, infak, arisan, dana program, dan takjil ramadhan. Penerimaan diperoleh dari infak anggota. Dana kas terbesar diperoleh dari arisan dan takjil ramadhan. Dana kas ramadhan akan dibagikan ke panti asuhan, rumah yatim, rumah qur'an, masjid, security, dan pengampu jalan. Pelaporan dilakukan untuk dana yang sudah jelas peruntukannya. Dana tabungan anggota, 
tidak termasuk dalam laporan yang disosialisasikan, karena berupa simpanan yang akan dikembalikan kepada pemilik ketika tiba waktunya Idhul Fitri/Adha.

MT Ummahat Al-Abror merupakan bagian dari Dewan Kemakmuran Masjid (DKM) Al-Abror, penyaluran dana untuk pemberdayaan usaha dilakukan oleh DKM sehingga tidak terjadi kebijakan yang tumpang tindih. Penyaluran dana tabungan untuk pemberdayaan ekonomi dilakukan belum secara terprogram, mengingat diperlukan pengelolaan kas yang detail dan dapat dipertanggung-jawabkan sehingga memerlukan pemikiran, pencatatan, dan seleksi debitur yang hati-hati. Alasan berikutnya adalah kondisi pandemi yang membatasi ruang gerak anggota demikian pula risiko yang dihadapi pengusaha, berupa ketidakpastian yang tinggi. Seleksi debitur dilakukan mulai dari anggota yang memiliki usaha kemudian berlanjut ke penduduk setempat yang memiliki usaha dan memerlukan tambahan dana jangka pendek.

DKM dan MT yang dikelola dengan menerapkan good governance dapat memotivasi anggota untuk menyimpan dana, sehingga dana menjadi lebih besar, demikian pula harapan memberi manfaat bagi pemberdayaan ekonomi. Pemberdayaan ekonomi memiliki peluang yang besar untuk dikembangkan dengan memanfaatkan dana tabungan anggota, namun sampai saat ini belum dapat dilaksanakan dengan baik, karena risiko bisnis yang besar pada kondisi pandemi.

\section{PEMBAHASAN}

\footnotetext{
Manajemen kas MT Ummahat Al_Abror menerapkan prinsip good governance, dengan 8 karakteristik. Manajemen dapat mempertanggungjawabkan dan menjawab keputusan dan tindakannya berdasarkan data yang tersedia
}

(akuntabilitas). Proses pengelolaan diketahui dan memiliki prosedur dan langkah-langkah yang jelas. Anggota dapat melihat dan menanyakan bagaimana suatu keputusan dibuat (transparan). Pemanfaatan dana dilakukan sesuai dengan program yang telah ditetapkan sehingga tidak melanggar ketentuan hukum yang berlaku. Anggota dapat memberi saran untuk penentuan jumlah iuran per periode demikian pula pengalokasiannya.

$$
\text { Penerapan good governance }
$$
dimulai dari identifikasi mekanisme, proses, dan outcomes. MT perlu menetapkan mekanisme (Dhaoui, 2019) dalam penyaluran dana pinjaman jangka pendek ke para anggota yang memerlukan. Gambar 1 menunjukkan mekanisme yang dapat dilakukan bagi MT guna menyalurkan kredit jangka pendek yang bersumber dari tabungan anggota.

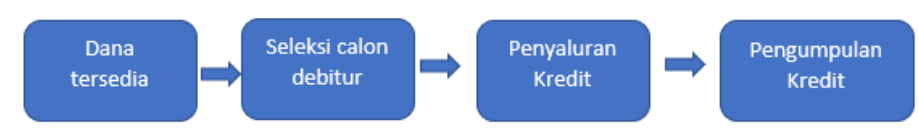

Gambar 1. Mekanisme Pemberian Kredit Jangka Pendek

Dana yang digunakan adalah tabungan anggota MT, sehingga prinsip hati-hati dalam penyaluran kredit jangka pendek harus dilakukan secara seksama, jangan sampai terjadi kredit macet. Penghimpunan dana dalam jumlah yang besar memerlukan ijin Otoritas Jasa Keuangan, sehingga terjadi pelanggaran hukum, apabila pengumpulan dana dilakukan dalam jumlah yang besar. Pencatatan perlu dilakukan dengan baik, walaupun secara sederhana dengan bantuan Excel, sehingga dapat diketahui keluar masuknya kas serta saldo setiap saat. Selanjutnya juga diperlukan pencatatan tabungan untuk masing-masing anggota.

Seleksi calon debitur mulai dari anggota yang dengan menerapkan 5C dan 
3R (Gitman, Lawrence J. and Zutter, 2015). Karakter memiliki posisi paling penting dalam penilaian. Hal ini yang menyebabkan penyaluran kredit diprioritaskan bagi anggota yang sudah dikenal sebagai jaminan. Anggota MT dapat memberi rekomendasi debitur dan besaran kredit yang dapat disalurkan. Rekomendasi ini juga dapat digunakan untuk penagihan jika terjadi kemacetan pengembalian.

Sejalan dengan pernyataan (Fox \& Romero, 2017) mengenai pemberdayaan ekonomi, idealnya penyaluran kredit diperuntukkan bagi usaha mikro sehingga dapat memperbesar modalnya dalam jangka pendek. Penyaluran kredit dilengkapi dengan pencatatan masingmasing debitur dan tanggal jatuh tempo. Jangka waktu kredit ditetapkan satu bulan, yang dapat diperbaharui bulan berikutnya. Penyaluran demikian agak merepotkan, namun dapat pula ditentukan untuk jangka waktu yang lebih panjang. Pengumpulan kredit dilakukan melalui sarana komunikasi seluler sehingga lebih cepat dan praktis, jika perlu ditransfer. Balas jasa atas kredit yang diberikan dilakukan berdasarkan konsep bagi hasil yang disepakati, sehingga tidak memberatkan pengusaha. Peluang kredit macet dapat saja terjadi, sehingga diperlukan cadangan yang diperoleh dari penyisihan atas bagi hasil yang diperoleh. Pengumpulan kredit dibatasi maksimum bulan Ramadhan, sehingga dana yang dititipkan anggota dapat tersedia kembali menjelang Hari Raya Idul Fitri.

\section{KESIMPULAN}

Berdasarkan kegiatan pengabdian kepada masyarakat yang dilakukan di Majelis Taklim Al Abror, diperoleh kesimpulan sebagai berikut: (1) manajemen kas dilakukan dengan menerapkan prinsip good governance, sehingga memungkinkan dana bertambah besar setiap saat, seiring dengan peningkatan kepercayaan. (2) pemberdayaan ekonomi kepada pengusaha mikro dilakukan melalui DKM dengan rekomendasi dari MT, (3) manajemen kas MT dapat berkontribusi pada peningkatan pemberdayaan ekonomi mikro dengan memanfaatkan simpanan sementara anggota menjadi pinjaman jangka pendek.

\section{DAFTAR PUSTAKA}

Dhaoui, L. (2019). Good governance for sustainable development. Munich Personal RePEc Archive, No. 92544 , 10.

DSN-MUI. (2017). Fatwa Dewan Syari'Ah Nasional Tentang Akad Mudharabah. Himpunan Fatwa DSN MUI, 115(19), 1-7.

DSN MUI. (2001). Fatwa Dewan Syari'ah Nasional No. 19/DSN-MUI/IV/2001 tentang Al-Qordh. Himpunan Fatwa DSN MUI, 1-4. http://mui.or.id/wpcontent/uploads/files/fatwa/19Qardh.pdf

Fox, L., \& Romero, C. (2017). In the Mind, the Household, or the Market? Journal of Business Research, 71(May), 191-203. https://doi.org/10.1016/j.wsif.2018.10 $.002 \% 0$ Ahttps://doi.org/10.1016/j.jbu sres.2019.01.045\%0Ahttps://openkno wledge.worldbank.org/handle/10986/ 26951

Gitman, Lawrence J. and Zutter, C. J. (2015). Principle of Management Finance (Fourteen). Pearson Education Limited.

Huda, I. (2020). Pemberdayaan Masyarakat Berbasis Multikultural di Majelis Taklim An Najach Magelang. Inferensi: Jurnal Penelitian Sosial Keagamaan, 13(2), 253-278. 
https://doi.org/10.18326/infs13.v13i2. 253-278

Indonesia, K. A. R. (2019). Peraturan Menteri Agama Republik Indonesia Nomor 29 Tahun 2019 Tentang Majelis Taklim.

Ipansyah, N., \& Helmi, R. (2014). Fikih Muamalat dalam Majelis Taklim di Kalimantan Selatan. 88 Tashwir, 2(3), 87-102.

Jazil, S. (2014). Fiqih Mu'amalah (A. Mansyuri (ed.); 1st ed.). UIN Sunan Ampel Press.

Nso, M. A. (2018). Cash Management Techniques and The Relationship Between Cash Management and Profitability of Microfinance Institutions. International Journal of Economics, Commerce and
Management United Kingdom, VI(5). http://ijecm.co.uk/

Ramlah, M. (2017). Dakwah di Kecamatan Wara Selatan Kota Palopo. Palita: Journal of Social-Religion Research, 2(1), 55-71.

Rugui, Lincoln and Omagwa, J. (2018). Effect of Financial Management Practices on Performance of Selected Small and Medium Enterprises in Limuru Town, Kenya. International Journal of Scientific and Education Research, 2(05), 51. https://doi.org/10.18843/ijms/v5i4(8)/ 06

Van Horne, James C; Wachowicz, John M., J. alih bahasa Q. M. (2012). Prinsip-prinsip Manajemen Keuangan (13. Buku I). Salemba Empat. 